\title{
PERBEDAAN PROPORSI GANGGUAN DEPRESI DAN GANGGUAN CEMAS ANTARA MAHASISWA PREKLINIK DAN KLINIK
}

Yoan Chou, Dharmady Agus, Dwi Jani Juliawati

Fakultas Kedokteran Universitas Katolik Indonesia Atmajaya, Jakarta - INDONESIA

\begin{abstract}
Background: Medical education is full of burden and pressure, so that medical students are prone to get depressive disorder and anxiety disorder. These have been proven by several researches conducted in the faculties of medicine from abroad as well as in Indonesia. Medical students, either preclinical or clinical, need to face many obstacles, but clinical students have more demands than preclinical students and they are directly responsible for patient safety. The more demands of the clinical students made them prone to have more depressive and anxiety disorder.

Method: This research was conducted as a cross-sectional study on 200 students on Atma Jaya Medicine Faculty by choosing 100 pre-clinical and clinical students with simple random sampling. Data were collected with structured interviews by using MINI ICD-10 instrument to determine the depressive and anxiety disorder.

Results: There were significant differences between the proportion of depressive disorder and anxiety disorder among preclinical and clinical students in FKUAJ 2015 ( $p=0.044$ and $p=0.048)$. The proportion of depressive disorder and anxiety disorder in clinical students are higher than preclinical students (29\% vs. $17 \%$ and 38\% vs. $25 \%)$.
\end{abstract}

Conclusions: Clinical students are more prone to get depressive disorder 1,99 times and anxiety disorder 1,84 times than preclinical students FKUAJ year 2015

Keywords: depressive disorder, anxiety disorder, preclinical students, clinical students

\begin{abstract}
ABSTRAK
Latar belakang: Pendidikan kedokteran adalah masa pendidikan yang berat dan penuh tekanan, sehingga mahasiswa kedokteran rentan terhadap gangguan depresi dan gangguan cemas. Hal ini telah dibuktikan oleh berbagai penelitian, baik pada fakultas kedokteran di luar negeri maupun di Indonesia. Mahasiswa kedokteran, baik preklinik maupun klinik harus menghadapi berbagai macam rintangan, namun mahasiswa klinik memiliki tuntutan yang lebih banyak dibandingkan dengan mahasiswa preklinik dan mahasiswa klinik bertanggung jawab langsung terhadap keselamatan pasien. Tuntutan yang lebih banyak pada mahasiswa klinik dapat menyebabkan mahasiswa klinik lebih rentan terhadap gangguan depresi dan gangguan cemas.

Metode: Desain penelitian ini adalah studi potong lintang lintang yang dilakukan pada 200 mahasiswa fakultas kedokteran Unika Atma Jaya dengan cara pemilihan 100 mahasiswa preklinik dan 100 mahasiswa klinik secara simple random sampling. Pengambilan data dilakukan dengan cara wawancara terstruktur dengan menggunakan instrumen MINI ICD-10 untuk menentukan gangguan depresi dan gangguan cemas.

Hasil: Terdapat perbedaan yang bermakna antara proporsi gangguan depresi dan gangguan cemas antara mahasiswa preklinik dan klinik di FKUAJ tahun 2015 ( $\mathrm{p}=0,044$ dan $\mathrm{p}=0,048)$. Proporsi gangguan depresi dan gangguan cemas pada mahasiswa klinik adalah lebih tinggi dibandingkan dengan mahasiswa preklinik ( $29 \%$ vs. $17 \%$ dan $38 \%$ vs. $25 \%$ ).
\end{abstract}

Contact: yoan.chou@yahoo.co.id 
Kesimpulan: Mahasiswa klinik memiliki risiko yang lebih tinggi untuk mengalami gangguan depresi sebesar 1,99 kali dan gangguan cemas sebesar 1,84 kali dibandingkan dengan mahasiswa preklinik FKUAJ tahun 2015.

Kata kunci: gangguan depresi, gangguan cemas, mahasiswa preklinik, mahasiswa klinik

\section{PENDAHULUAN}

Gangguan depresi dan gangguan cemas merupakan gangguan yang dapat terjadi pada setiap individu, termasuk mahasiswa kedokteran. Gangguan depresi adalah gangguan mental umum yang ditandai dengan gangguan perasaan atau mood, kehilangan minat atau kesenangan, perasaan bersalah atau harga diri yang rendah, susah tidur, penurunan nafsu makan, energi rendah, dan konsentrasi yang buruk. ${ }^{1}$ Kesedihan dan penolakan merupakan gejala emosional yang paling menonjol dalam gangguan depresi. ${ }^{2}$ Sementara itu, gangguan cemas merupakan masalah psikologis yang sering dialami pada usia remaja dan merupakan suatu respons fisiologis otak terhadap suatu ancaman yang berusaha dihindari oleh setiap orang. Biasanya hal ini terjadi dalam menghadapi sesuatu yang baru/ belum pernah dicoba dan saat dalam pencarian identitas diri. ${ }^{3}$ Gangguan cemas ditandai dengan perasaan ketakutan disertai tanda somatik berupa sistem saraf otonom yang hiperaktif seperti sakit kepala, keringat, jantung berdebar, dan sesak ringan di dada dan perut. Gangguan depresi dan gangguan cemas dapat disebabkan oleh berbagai hal yang dipengaruhi faktor biologi, psikologi, dan sosial individu tersebut. ${ }^{4}$

Lebih dari 350 juta penduduk dunia mengalami gangguan depresi dan diperkirakan 1 dari 10 orang menderita gangguan cemas., ${ }^{5,6}$ Di Fakultas Kedokteran Indonesia, Fakultas Kedokteran Universitas Katolik Indonesia Atma Jaya (FKUAJ) pernah melakukan penelitian perihal prevalensi gangguan depresi pada mahasiswa kedokteran angkatan 2007. Hasilnya adalah 34,9\% mahasiswa kedokteran memiliki gangguan depresi.?

Seperti yang kita ketahui, pendidikan dokter adalah pendidikan yang diselenggarakan untuk menghasilkan dokter yang memiliki kompetensi untuk melaksanakan pelayanan kesehatan primer. ${ }^{8}$ Pendidikan kedokteran bertanggung jawab untuk memastikan bahwa setiap lulusan memiliki pengetahuan, dan terampilan yang baik, juga harus professional.9,10 Pendidikan kedokteran terdiri dari dua tahap, yaitu tahap sarjana kedokteran dan tahap profesi dokter. Pada tahap sarjana kedokteran mahasiswa kedokteran preklinik mempelajari ilmuilmu kedokteran dasar yang telah tersusun sebagai Program Studi Sarjana Kedokteran (PSSK) dan diakhiri dengan gelar Sarjana Kedokteran (S.Ked). ${ }^{8}$ Sementara itu, tahap profesi dokter adalah tahap yang harus dilalui oleh mahasiswa klinik untuk mendapatkan gelar Dokter (dr.), dimana mahasiswa klinik berlatih secara mendalam melakukan anamnesis, pemeriksaan fisik, pembuatan catatan medik, analisis keluhan atau hasil pemeriksaan fisik penderita, dan penentuan serta penyelesaian problem-problem medik penderita dari setiap stase yang telah tersusun dalam Program Studi Profesi Dokter (PSPD)..$^{11,12}$ Tentunya terdapat perbedaan metode pembelajaran antara tahap pendidikan sarjana kedokteran dan tahap profesi dokter. Pada FKUAJ, metode pembelajaran yang diterapkan pada tahap pendidikan sarjana kedokteran adalah perkuliahan, SCL (Student Centre Learning), praktikum, skills lab, case base learning, field study, journal reading, dan referat. Disisi lain, metode pembelajaran pada tahap profesi dokter adalah independent learning, e-learning, case base learning, case base teaching, bed side teaching, morning report, journal reading, dan referat. ${ }^{13}$ Berbagai macam metode pembelajaran ini bertujuan untuk meningkatkan kualitas mahasiswanya. Sayangnya, beberapa aspek proses pendidikan ada yang berdampak negatif pada kesehatan mental mahasiswa. Secara umum gangguan depresi dan gangguan cemas pada mahasiswa kedokteran, baik mahasiswa preklinik maupun klinik, dapat 
disebabkan oleh ketidakmampuan adaptasi terhadap lingkungan pendidikan kedokteran, hubungan interpersonal yang buruk antara dosen dan mahasiswa, pelecehan institusional, dan permasalahan pribadi kehidupan. ${ }^{14}$

Mahasiswa kedokteran klinik memiliki beberapa stresor yang tidak dimiliki mahasiswa kedokteran preklinik seperti tuntutan yang tinggi dan beragam pada mahasiswa klinik, tingginya persaingan antara mahasiswa klinik, pemaparan terhadap kematian dan penderitaan manusia, jadwal yang padat, pelecehan, dan diskriminasi pada mahasiswa klinik. ${ }^{15}$ Atas dasar itu, dapatlah diprediksi bahwa mahasiswa klinik lebih rentan terhadap gangguan depresi dan gangguan cemas dibandingkan dengan mahasiswa preklinik. Gangguan depresi dan gangguan cemas yang terjadi pada mahasiswa kedokteran tentunya akan berdampak buruk pada mahasiswa tersebut seperti terjadinya penurunan kinerja akademik, kehilangan integritas akademis, ketidakjujuran akademis, ketergantungan alkohol/ zat, dan bunuh diri. ${ }^{14,15}$

Berdasarkan fakta bahwa faktor penyebab gangguan depresi dan gangguan cemas yang terjadi pada mahasiswa kedokteran cukup banyak, terutama untuk mahasiswa klinik, maka peneliti ingin melihat apakah terdapat perbedaan proporsi gangguan depresi dan gangguan cemas antara mahasiswa preklinik dan klinik. Tujuan penelitian ini ingin membuktikan bahwa terdapat perbedaan proporsi gangguan depresi dan gangguan cemas antara mahasiswa preklinik dan klinik pada FKUAJ tahun 2015. Hasil penelitian ini diharapkan dapat menjadi refleksi bagi penyelenggara institusi fakultas kedokteran, staf pengajar, dan mahasiswa untuk memulai mencari akar permasalahan gangguan depresi dan gangguan cemas dan berupaya terus untuk menciptakan strategi pembelajaran yang lebih baik bagi mahasiswa kedokteran.

\section{METODE}

Penelitian ini merupakan penelitian potong lintang yang dilakukan pada mahasiswa fakultas kedokteran Unika Atma Jaya pada tahun 2015. Variabel bebas dalam penelitian ini berupa proporsi gangguan depresi dan gangguan cemas antara mahasiswa preklinik dan klinik. Sementara itu, varibel terikat dalam penelitian berupa perbedaan proporsi gangguan depresi dan gangguan cemas antara mahasiswa preklinik dan klinik. Sampel penelitian terdiri dari 100 mahasiswa preklinik dari angkatan 2015, angkatan 2014, angkatan 2013, dan angkatan 2012 dan 100 mahasiswa klinik dari angkatan 2011 dan angkatan 2010 yang menempuh pendidikan dokter umum di FKUAJ, yang dipilih dengan menggunakan teknik simple random sampling. Pengambilan data dilakukan secara wawancara terstuktur dengan menggunakan instrumen penelitian MINI ICD-10 untuk menentukan gangguan depresi dan gangguan cemas.

Uji statistik yang digunakan pada penelitian ini adalah uji Chi-square (uji nonparametrik) karena jenis penelitian ini merupakan deskriptif kategorik dengan distribusi data yang tidak normal. Kenormalan data diuji dengan parameter Kolmogorov-Smirnov. Perbedaan proporsi gangguan depresi dan gangguan cemas dikatakan bermakna, jika $\mathrm{p}<0,05$.

\section{HASIL DAN PEMBAHASAN}

Penelitian yang dilaksanakan pada bulan Desember 2015 - Maret 2016 ini berhasil mewawancarai 200 mahasiswa FKUAJ. Karakteristik responden dapat dilihat pada tabel berikut (Tabel 1).

Tabel 1. Karakteristik responden

\begin{tabular}{lcccc}
\multicolumn{1}{c}{ Karakteristik } & $\begin{array}{c}\text { Preklinik } \\
\%\end{array}$ & $\begin{array}{c}\text { Klinik } \\
\%\end{array}$ & P \\
Jenis & Perempuan & 59 & 76 & 0.01 \\
Kelamin & Laki laki & 41 & 24 & \\
\hline \multirow{4}{*}{ Tahun } & 2010 & - & 43 & 0 \\
Angkatan & 2011 & - & 57 & \\
& 2012 & 31 & - & \\
& 2013 & 22 & - & \\
& 2014 & 23 & - & \\
\hline
\end{tabular}

Karakteristik tahun angkatan adalah homogen di antara kedua kelompok (preklinik dan klinik). Namun demikian, untuk jenis kelamin adalah tidak homogen. Tidak homogennya karakterisktik jenis kelamin dikarenakan jumlah mahasiswa FKUAJ 
yang berjenis kelamin perempuan adalah selalu lebih banyak dibandingkan dengan mahasiswa laki laki. Dengan demikian, secara keseluruhan dapat disimpulkan bahwa karakteristik responden kedua kelompok penelitian ini adalah homogen.

\section{Proporsi Gangguan Depresi dan Gangguan Cemas pada Mahasiswa Preklinik dan Klinik di FKUAJ}

Berikut ini dipaparkan data proporsi gangguan depresi (Tabel 2) dan gangguan cemas (Tabel 3) antara mahasiswa preklinik dan klinik di FKUAJ.

Tabel 2. Proporsi gangguan depresi antara mahasiswa preklinik dan klinik

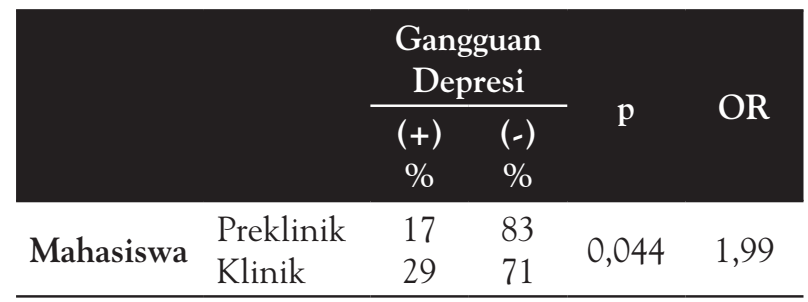

Tabel 3. Proporsi gangguan cemas antara mahasiswa preklinik dan klinik

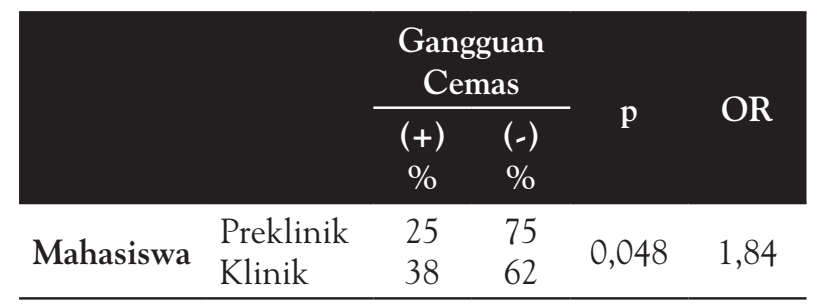

Hasil penelitian ini menunjukkan bahwa terdapat perbedaan yang bermakna antara proporsi gangguan depresi dan gangguan cemas mahasiswa preklinik dan klinik di FKUAJ tahun $2015 \quad(\mathrm{p}=0,044$ dan $\mathrm{p}=0,048)$. Proporsi gangguan depresi pada mahasiswa klinik adalah lebih tinggi dibandingkan dengan mahasiswa preklinik (29\% vs. $17 \%)$. Demikian juga proporsi gangguan cemas pada mahasiswa klinik adalah lebih tinggi dibandingkan dengan mahasiswa preklinik (38\% vs $25 \%)$. Berdasarkan nilai odds ratio (OR), mahasiswa klinik lebih berisiko mengalami gangguan depresi 1,99 kali dan 1,84 kali untuk gangguan cemas dibandingkan dengan mahasiswa preklinik. ${ }^{16}$ Beberapa faktor yang dapat menyebabkan proporsi gangguan depresi dan gangguan cemas pada mahasiswa klinik lebih tinggi dibandingkan dengan mahasiswa preklinik, antara lain:

a. Tuntutan yang tinggi dan beragam pada mahasiswa klinik.

Setiap stase kepaniteraan klinik membutuhkan pengetahuan medis dasar dan keahlian yang unik. Mahasiswa klinik harus menguasai berbagai macam kemampuan klinis dan keterampilannya dalam waktu yang singkat. Memang mahasiswa preklinik maupun klinik dituntut untuk menguasai berbagai ilmu kedokteran, namun mahasiswa klinik tidak hanya harus menghadapi ujian sebagai syarat kelulusan suatu stase, tetapi mahasiswa klinik juga dituntut untuk mengaplikasikan ilmu tersebut dengan baik dan bertanggung jawab terhadap kesehatan dan keselamatan pasien. Tuntutan yang sedemikian tinggi dan beragam tersebut dapat menimbulkan kekhawatiran yang tinggi pada mahasiswa klinik dan rasa frustrasi. Tingkat stres pada mahasiswa klinik semakin diperparah, apabila mahasiswa klinik tersebut kurang berminat pada stase yang sedang dijalaninya, sehingga mahasiswa klinik tersebut merasa segala tuntutan yang harus ia penuhi sebagai suatu beban yang sangat berat. Ada kalanya tekanan datang dari konsulen, perawat, keluarga pasien, dan pasien itu sendiri, yang akan semakin menambah beban berat pada mahasiswa klinik. Hal-hal tersebut dapat meningkatkan risiko gangguan depresi dan gangguan cemas pada mahasiswa klinik. ${ }^{15}$

b. Tingginya persaingan antara mahasiswa klinik Suasana belajar di rumah sakit yang berhadapan langsung dengan pasien adalah lebih kompetitif dibandingkan dengan suasana belajar mahasiswa preklinik di universitas, karena mereka berhadapan langsung dengan staf pengajar di rumah sakit dan rekan-rekannya. Mahasiswa klinik tidak ingin ketinggalan dari teman temannya dalam keterampilan menangani pasien. Perasaan takut kalah dalam persaingan, takut lebih buruk dibandingkan dengan teman temannya, takut tidak dapat memenuhi ekspetasi yang tinggi dari diri sendiri maupun orang lain (terutama pengujinya) 
dapat menimbulkan kekhawatiran, ketakutan, dan keputusasaan yang tinggi yang pada akhirnya dapat menyebabkan gangguan depresi dan gangguan cemas pada mahasiswa klinik. ${ }^{17}$

c. Pemaparan terhadap kematian dan penderitaan manusia

Mahasiswa klinik seringkali dihadapkan pada kondisi pasien yang sekarat atau dalam sakaratul maut atau kematian. Suatu studi menunjukkan bahwa sebagian besar mahasiswa klinik merasa khawatir dan kebingungan dalam menghadapi kondisi akhir kehidupan, terutama pada pasien meninggal yang pertama kali dihadapi oleh mereka. ${ }^{18}$ Ketidaksiapan mahasiswa klinik menghadapi pasien sekarat dan/atau kematian pasien dapat disebabkan oleh kurangnya pengetahuan dan pengalaman mahasiswa klinik dalam menghadapi pasien dengan kondisi tersebut. Kurikulum pendidikan kedokteran lebih sering memfokuskan pendidikan mengenai diagnosis dan pengobatan penyakit dibandingkan dengan pendidikan tentang akhir kehidupan. Tidak mengherankan bahwa mahasiswa klinik akan ketakutan, cemas, raguragu, dan frustrasi dalam menghadapi pasien dengan kondisi demikian, yang pada akhirnya dapat meningkatkan risiko gangguan depresi dan gangguan cemas.

d. Jadwal yang padat.

Mahasiswa klinik menghabiskan waktu lebih banyak di rumah sakit, sementara itu mahasiswa preklinik lebih banyak menghabiskan waktu di ruang kuliah. Setiap mahasiswa klinik memiliki jadwal jaga masing-masing dan berbagai aktivitas kepaniteraan klinik yang menguras tenaga. Setelah melakukan berbagai aktivitas rutin kepaniteraan klinik di rumah sakit setiap hari di pagi dan siang hari seperti morning report, ronde bangsal, tutor, dll, terkadang mereka harus berlanjut dengan jaga malam. Selain itu mahasiswa klinik juga harus belajar untuk ujian dan menyelesaikan berbagai tugas dari konsulen dalam waktu yang pendek dan terlalu padat itu. Hal ini menimbulkan kelelahan dan kejenuhan pada mahasiswa klinik. ${ }^{15}$ Sebuah studi menunjukkan bahwa sebagian besar mahasiswa klinik mengalami penurunan kualitas hidup dan kualitas tidur karena padatnya aktivitas mereka. Penurunan kualitas tidur pada mahasiswa klinik dapat mengganggu metabolisme tubuh seperti penurunan hormon serotonin dan dopamin yang dihasilkan saat seseorang tertidur. Berdasarkan hasil penelitian, penurunan hormon serotonin dan dopamin dapat menyebabkan gangguan depresi pada seseorang. Penurunan kualitas tidur secara terus menerus juga dapat mengakibatkan penurunan kualitas hidup seseorang, yang pada gilirannya dapat mengganggu kesehatan mental mahasiswa klinik di antaranya adalah gangguan depresi dan gangguan cemas. Performa akademik mahasiswa klinik juga akan menurun seiring dengan terjadinya gangguan depresi dan gangguan cemas. ${ }^{19-21}$ Persoalan akan seperti fenomena bola salju yang akan semakin membesar seiring dengan adanya gangguan cemas dan gangguan depresi pada mahasiswa klinik.

e. Pelecehan dan diskriminasi pada mahasiswa klinik

Studi menunjukkan bahwa 50\%-85\% mahasiswa kedokteran yang mengalami pelecehan akan mengalami gangguan depresi dan gangguan cemas dan prevalensinya adalah lebih tinggi pada mahasiswa klinik. Pelecehan yang dapat terjadi pada mahasiswa kedokteran antara lain pelecehan verbal, pelecehan institusional, pelecehan fisik, pelecehan seksual, dan diskriminasi. Berbagai bentuk pelecehan pada mahasiswa klinik dapat menurunkan kepercayaan dan harga dirinya. Mahasiswa klinik akan selalu merasa tidak pantas, takut untuk berbuat salah, dan khawatir berlebihan yang pada gilirannya dapat menurunkan performa belajar dari mahasiswa klinik. Bila hal ini berlanjut, maka kondisi ini dapat meningkatkan risiko untuk mengalami gangguan depresi dan gangguan cemas pada mahasiswa klinik ${ }^{15,16}$

\section{KESIMPULAN}

Hasil penelitian ini menunjukkan bahwa terdapat perbedaan bermakna gangguan depresi dan gangguan cemas antara mahasiswa preklinik dan klinik FKUAJ. 
Proporsi gangguan depresi dan gangguan cemas pada mahasiswa klinik adalah lebih tinggi dibandingkan dengan mahasiswa preklinik. Mahasiswa klinik lebih berisiko mengalami gangguan depresi 1,99 kali dan 1,84 kali untuk gangguan cemas dibandingkan dengan mahasiswa preklinik

\section{SARAN}

Agar gangguan depresi dan gangguan cemas dapat menurun pada mahasiswa kedokteran, baik preklinik maupun klinik, selama menempuh pendidikan kedokteran, maka penyelenggara institusi fakultas kedokteran dan staf pengajar fakultas kedokteran memberikan bantuan, perhatian, dan dukungan kepada mahasiswa, terutama yang mengalami gangguan depresi dan gangguan cemas akibat dari kegiatan akademik yang dihadapinya. Kepada mahasiswa kedokteran disarankan untuk lebih banyak berpikir positif. Terapi relaksasi dapat digunakan sebagai salah satu cara dalam menghadapi gangguan depresi dan gangguan cemas. Selain itu, perlu penelitian lebih lanjut untuk mencari determinan penentu yang dapat menyebabkan gangguan depresi dan gangguan cemas pada mahasiswa klinik yang proporsinya lebih tinggi dibandingkan dengan mahasiswa preklinik.

\section{DAFTAR PUSTAKA}

1. [WHO] World Health Organization. Depression [internet]. 2012 [cited 6 apr 2015]; Avaiable from http://www.who.int/ topics/ depression/en/

2. Atkinson RL, Atkinson RC, Smith EE, Bem DJ, Hoeksema SN. Hilgard's Introduction to Psychology, 15th edition. United States of America; 2009

3. Chandratika D, Purnawati S. Gangguan cemas pada Mahasiswa Semester I dan VII Program Studi Pendidikan Fakultas Kedokteran Universitas Udayana [internet]. 2014 [cited 23 nov 2015]; available from: Google Scholar

4. Kaplan, H.I \& Saddock, B.J. Synopsis of Psychiatry. 11th ed. Lange Medical Publication Maruzen, Co. Ltd.; 2014.

5. [WHO] World Health Organization. DEPRESSION A Global public health concern [internet].2012 [cited 23 nov 2015]; Available from http:/www. who.int/ mental_health/management/depression/ who_paper_depression_wfmh_2012.pdf
6. Departemen Kesehatan Indonesia, editor. Pedoman penggolongan diagnosis gangguan jiwa di Indonesia III (PPDGJ III). Cetakan pertama. Jakarta: Departemen Kesehatan RI, Direktorat Bina Kesehatan Masyarakat; 2004.

7. Agustinus DH, Agustinus DH, Charles S, Satya J. Prevalensi depresi dan faktor yang mempengaruhi pada mahasiswa fakultas kedokteran universitas katolik Indonesia atma jaya angkatan 2007 [skripsi]. Jakarta (Indonesia): Universitas Katolik Indonesia Atma Jaya; 2010.

8. Konsil Kedokteran Indonesia. Standar Pendidikan Profesi Dokter. Jakarta: Konsil Kedokteran Indonesia; 2006

9. Liasion Committee on Medical Education. Functions and structure of a medical school: Standards for accreditation of medical education programs leading to the M.D. degree. 2003 [Internet]. 2003 [cited 23 nov 2015]; Available from: www. lcme. org/ functions2003march. pdf;

10. [AAMC] Association of American Medical Colleges. Report I. Learning Objectives for medical student education: guidelines for medical schools. medical schools objectives project [Internet]. 1998 [cited 24 okt 2015]; Available from: www. aamc. org/meded/msop/msop1.pdf.

11. [FKUAJ] Fakultas Kedokteran UNIKA Atma Jaya. Program studi profesi dokter [Internet]. 2015 [cited 23 nov 2014]; available from: http:// www.atmajaya. ac.id/web/ Konten Fakultas. aspx?gid-infofakultas\& cid=programstudiprofesidokter\&ou=kedokteran\#st hash8paVjzZi.dpuf

12. Firmansyah R. Faktor faktor yang mempengaruhi kepuasan mahasiswa kedokteran terhadap pelatihan keterampilan klinik di tahap sarjana: studi kasus di FK UNDIP [skripsi]. Semarang (Indonesia) : Universitas Diponegoro; 2012.

13. [FKUAJ] Fakultas Kedokteran UNIKA Atma Jaya. Metode pembelajaran sistem KBK Atma Jaya Kedokteran [Internet]. 2015 [cited 23 nov 2014]; available from: http://www.atmajaya. ac.id/ web/ KontenFakultas.aspx?gid=infofakultas \& cid = metode-pembelajarankbk\&ou=kedokteran

14. Dyrbye LN, Thomas MR, Shanafelt TD. Medical student distress: causes, consequences, and proposed solutions [internet]. 2005 [cited 29 may 2016]; available from : mayo clinic

15. Kitchen, Lynn. Suicide among medical students. [Internet]. [cited 10 apr 2015]; Available from: http:// www. ncbi.nlm.nih.gov/pmc/articles/ 


\section{PMC1238419.}

16. Chou, Yoan. Perbedaan proporsi gangguan depresi dan gangguan cemas antara mahasiswa preklnik dan mahasiswa klinik FKUAJ tahun 2015 [karya tulis ilmiah]. Jakarta (Indonesia): Universitas Katolik Indonesia Atma Jaya; 2016

17. Rahmawati AT. Perbedaan derajat depresi antara mahasiswa kedokteran preklinik dan klinik Universitas Islam Negeri Syarif Hidayatullah Jakarta tahun 2012. Universitas Islam Negeri Syarif Hidayatullah; 2012.

18. Academic Medicine. Face to face with It : Medical students' narratives about their end-of-life education [internet]. 2002 [cited 29 may 2016]; Avaliable from: http:// journals.lww.com/ academicmedicine/ Abstract/ 2002/ 04000/_Face_to_face_with_It
Medical_Students_.3.aspx

19. Goldin SB, et al. Student quality-of-life declines during third year surgical clerkship. 2007 [cited 23 nov 2015]; Available from:http://www.ncbi.nlm. nih.gov/pubmed/17950086

20. Lubis L N. Depresi Tinjauan Psikologis. Ed ke-1. Jakarta: Kencana; 2009.

21. Samaranayake CB, Arroll B, Fernando AT. Sleep disorders, depression, anxiety and satisfaction with life among young adults: a survey of university students in Auckland, New Zealand[internet]. 2014 [cited 23 nov 2015]. Available from: ncbi. 